\title{
Analysis of price transmission of fresh tomato and pineapple in the rural and urban markets of Akwa Ibom Sate, Nigeria
}

\author{
Sunday Brownson Akpan ${ }^{1}$, Ini-Mfon Vincent Patrick ${ }^{1}$, Glory Emmanuel Edet ${ }^{2}$, \\ Daniel Etim John ${ }^{2}$ \\ ${ }^{1}$ Department of Agricultural Economics and Extension, Akwa Ibom State University, Nigeria \\ ${ }^{2}$ Department of Agricultural Economics and Extension, University of Uyo, Akwa Ibom State, Nigeria

\section{Email address:} \\ brownsonakpan10@gmail.com (Sunday B. A.), inivipako@gmail.com (Ini-Mfon V. P.), gakanmkpo@yahoo.com (Glory E. E.), \\ dannyj2004@yahoo.com (Daniel E. J.)
}

\section{To cite this article:}

Sunday Brownson Akpan, Ini-Mfon Vincent Patrick, Glory Emmanuel Edet, Daniel Etim John. Analysis of Price Transmission of Fresh Tomato and Pineapple in the Rural and Urban Markets of Akwa Ibom Sate, Nigeria. American Journal of Agriculture and Forestry. Vol. 2, No. 3, 2014, pp. 66-78. doi: 10.11648/j.ajaf.20140203.13

\begin{abstract}
The study investigated the dynamics of price transmission and market integration of fresh tomato and pineapple in the rural and urban markets of Akwa Ibom State, Nigeria. Average monthly prices (measured in naira per kilogram) of fresh tomato and pineapple in the rural and urban markets were used in the analysis. The data was obtained from the quarterly publications of the Akwa Ibom State Agricultural Development Programme (AKADEP). The data covered the period from January 2005 to September 2013. The trend analysis showed that, prices of fresh tomato and pineapple in the rural and urban markets have positive significant relationships with time and positive exponential growth rate. The Pearson correlation coefficient of each of the respective pair of rural and urban price of fresh tomato and pineapple revealed significant positive and symmetric relationships. The bivariate Granger causality test revealed bi-directional relationships between the rural and urban price of fresh tomato and pineapple in the State. The co-integration test revealed the presence of co-integration between the rural and urban price of fresh tomato and pineapple. The coefficients of market integration in the rural and urban price equation display varied degrees of long run market integration. The results of the error correction model (ECM) confirmed the existence of the short run market integration between the rural and urban prices of fresh tomato and pineapple in the study area. The urban price of fresh tomato adjusted faster to the stable state in the long run than its respective rural price. Also the rural price of pineapple adjusted faster to a stable state in the long run than its respective urban price. The index of market connection for fresh tomato and pineapple supported the existence of the short run market integration between the rural and urban markets. Based on the findings, it is recommended that, the Akwa Ibom State government should continue to provide marketing infrastructures in the rural areas to improve the symmetric nature of information among fresh tomato and pineapple markets in the state. Effort should also be channeled by all stake holders such as governments, trade unions and other organizations to reduce excessive externality costs associated with the marketing of fresh tomato and pineapple in the state. The government of Akwa Ibom State should established market information centers and awareness programmes on mass media to facilitate efficient information flow among fresh tomato and pineapple producers and consumers in the state.
\end{abstract}

Keywords: Market, Fresh Tomato, Price, Integration, Pineapple, Akwa Ibom, Nigeria

\section{Introduction}

Fruit is considered as the sweet and fleshy product of a tree or other plant that contains seed and can be eaten as food. Fruits and vegetables play significant roles in human nutrition, especially as sources of vitamins (C, A, B6, thiamine, niacin, E), minerals, and dietary fiber $[26,27,30]$.
Fresh tomato and pineapple is among the most important fruits in Nigeria. Fruits are generally high in fiber, water, vitamins, and sugars among others. Several reports have shown that adequate intake of fruits and vegetables form an important part of a healthy diet; as low fruit and vegetable intake constitute a risk factor for chronic diseases such as cancer, coronary heart disease (CHD), stroke and cataract 
formation [29]. Scientific evidence indicates that frequent consumption of fruits and vegetables can prevent oesophageal, stomach, pancreatic, bladder and cervical cancers and that a diet high in fruits and vegetables could prevent $20 \%$ of most types of cancers [11].

Tomato (Solanum lycopersicum) and pineapple (Ananas comosus) are among fruit crops cultivated in most areas of Nigeria. These crops are characterized by problems of seasonality, bulkiness and high perishable nature. The persistence of these problems affects production and marketing of these agricultural commodities. Due to the difficulty in the handling of fresh tomato and pineapple among farmers, price variation is a regular phenomenon in Nigeria. Price variation in fresh tomato and pineapple differs among regions, state, local government, rural and urban centers. Price been the coordinating cell for agricultural production and marketing; it determines resource allocation and utilization in the agricultural sector. In the context of the marketing environment, price shows the level of efficiency and the working mechanism among agricultural product markets. In a poverty stricken society like Nigeria, price is one of the fundamental determinants of consumer preference and taste [4]. Many researches in Nigeria have related price volatility in agricultural commodities to several factors including variances in bargaining power among consumers, cyclical income fluctuation among sellers and consumers, seasonality of production, natural shocks such as flood, pests, diseases, and inappropriate response by farmers to price signals [12, $1,4]$. Instability in commodity prices among markets could be detrimental to the marketing system and the economy as a whole. It could cause inefficiency in resources allocation among sellers and consumers depending on the source of variability (that is, whether it is induce by supply or demand side or both). It could also increase poverty level among low income earners in the society [25]. On the other hand, a unified product price among spatial markets might not be a rational policy to pursue in a developing country like Nigeria. This is because of the deteriorating marketing infrastructures, increase in cost of externalities and the nature of most agricultural products which often resulted in significant differences in the total variable costs incurred by sellers and consumers in these markets.

Nigeria is a vast country with clear distinct regions, rural and urban areas. Prices of agricultural commodities in each of this region, rural and urban areas differ depending on the availability of infrastructures among others. Spatial price linkages are often interpreted as providing insight into the efficiency of infrastructures of markets. This is especially true in developing economy or society, where infrastructure issues such as road systems, market development, transportation, and so forth may be especially pertinent [15]. In separated markets, when there is significant price difference between homogenous goods, such that the differences exceeded the transfer cost; the arbitrage activities will be stimulated. The arbitrageur will purchase commodities from lower-price markets and resale in higher-price markets. This is a situation where spatial markets are not integrated. On the other hand, two markets are integrated when there is a significant long-run relationship between prices of homogenous goods due to the smooth transmission of price signals and information across the two markets $[22,4]$. Market integration could be perfect if price changes in one market are fully and instantaneously reflected in the alternative markets [14].

Hence, understanding the direction and magnitude of fresh tomato and pineapple price transmission between the rural and urban markets in a state like "Akwa Ibom" will provide indispensable input to policy makers to formulate workable policies for the agricultural sector in the state. It will also, promote the achievement of the self food sufficiency drive and help in minimizing the menace of poverty among citizenry in the state. For instance, the extent of market integration has often been used to measure the success of market liberalization and structural adjustment policies in developing countries [18]. Therefore, such information can help government at all tiers to decide the extent to which price transmission can be considered as efficient across different geo-political zones in their domains.

Several empirical investigations have delved into agricultural price transmission and market integration of food stuffs in Nigeria. For instance, Amusa, [7] in her study of the trend analysis of agricultural food prices in Nigeria reported that, food items such as vegetable oil, Garri, brown beans, ripe plantains, fresh tomatoes, green vegetables, onion bulbs, shelled melon seeds, experienced increase and fluctuations in their prices. Also, Okoh and Egbon [22] examined the integration of Nigeria's rural and urban foodstuffs markets. The study concludes that, the rural and urban foodstuffs markets were well integrated. The result further suggested that, the urban market price drives the rural market price. The size of the adjustment coefficient for the rural foodstuffs price revealed that, the speed of adjustment from disequilibrium was moderate. Similarly, Ohen et al., [20] studied the vertical and horizontal price linkages for live catfish in Nigeria. The price variables used in the analysis were non-stationary and therefore were made stationary by first difference. The Johansen co-integration analysis was used to test for the relationship between prices. Results indicated that producer and export prices were co-integrated. Furthermore, the Granger causality Wald test suggested that, the retailed prices do have a causal relationship with producer prices. The dynamic regression analysis of prices also revealed that, the markets for live catfish have strong price linkages and thus are spatially integrated. In western Nigeria, Adeoye et al., [3] examined the price transmission and market integration of banana and plantain in Oyo state, Nigeria. Six market links rejected their respective null hypothesis of no Granger causality $(\mathrm{P}>0.05)$, two of the market links exhibited bi-directional Granger causality or simultaneous feedback relationship; while four market links exhibited uni-directional Granger causality at 5\% and 10\% level of significance. Urban plantain market occupies the leadership position in the commodity price formation and 
transmission in the markets investigated. The Index of market connection or concentration (IMC) indicated that, the markets exhibited low short run integration. In addition, Ojiako et al., [21] studied the spatial integration and price transmission in selected cassava products' (Lafun) markets in Nigeria. The study employed Vector Error Correction (VEC) model methodology. The result revealed the presence of the long-run equilibrium following exogenous shocks in the market. In addition, the result discovered unilateral Granger causality that runs from the rural to the urban market. The impulse response analysis revealed that, the rural price was more responsive to shocks emanating from the urban market, the effect of which was computed as $95.6 \%$ using the forecast error variance decompositions. The study further discovered that, the effects of the rural prices' shock on urban price were very negligible at $3.2 \%$ after 10 weeks. The implication is that the rural market was the dominant market for determining the price of lafun in the short-run. The error correction model revealed significant causality link between the peripheral and central markets, suggesting a clear trend in price leadership. In the South-South region, Akpan et al., [4] examined the price transmission and market integration of local and foreign rice in rural and urban markets of Akwa Ibom State. The findings showed that, price of local and foreign rice in rural and urban markets has constant exponential growth rate of $0.59 \%$ which suggests perfect co-movement for rural and urban prices of local and foreign rice in the study area. Also, the Pearson correlation coefficient matrix revealed that, the rural price of local and foreign rice has linear symmetric relationships with their corresponding urban prices. The Granger causality test revealed bi-directional relationship between rural and urban price of local and foreign rice. The results of the co-integration test revealed the presence of co-integration between the rural and urban prices of local and foreign rice as well as support the hypothesis of perfect price transmission between the two markets. The results of the error correction (ECM) model also confirm the existence of the short run market integration between the rural and urban prices of local and foreign rice in the study area. In addition, the result shows that, the price of local rice in both rural and urban markets adjusted faster than prices of foreign rice once there is an exogenous shock in the marketing process of rice. The index of market connection (IMC) supported the high short run market integration between prices in rural and urban markets for local and foreign rice commodities and the quick adjustment of rural price of local rice in relative to rural price of foreign rice.

From the reviewed literature, it is cleared that, fruit price transmission studies has not enjoyed good patronage from the Nigeria's researchers. Fruit is important in the dairy dietary need of individuals. Balance diet and self food sufficiency pursuit of all tiers of government cannot be achieved without the contributions of the fruit and vegetable food stuffs. Hence, this study is designed to specially provide dynamic information on fresh tomato and pineapple marketing in Akwa Ibom State, Nigeria. Study like this will provide effective policy variables needed to formulate workable marketing policies and assessing the efficiency of fruit price transmission as well as availability of social infrastructures in the southern Nigeria. The specific objectives were to:

$>$ examine the trends of the monthly prices $(\mathrm{N} / \mathrm{Kg})$ of fresh tomato and pineapple in the rural and the urban markets of the study area.

$>$ assess the nature of price transmission of fresh tomato and pineapple in the rural and urban market of the study area, and examine the degree of long and short market integration of fresh tomato and pineapple in the study area.

\subsection{Research Hypotheses}

Ho: Price trend in fresh tomato and Pineapple do not differ in rural and urban markets of Akwa Ibom State.

Ho: Price transmission of fresh tomato and pineapple in the rural and urban markets is not symmetric in Akwa Ibom State.

Ho: There are no long and short run relationships between prices of fresh tomato and pineapple in the rural and urban markets in the study area.

\section{Research Methodology}

\subsection{Study Area and Data Source}

The study was conducted in Akwa Ibom State located in the coastal South-South region of Nigeria. The state is located between latitudes $4^{\circ} 32^{1}$ and $5^{\circ} 33^{1}$ north and longitudes $7^{\circ} 25^{1}$ and $8^{\circ} 25^{1}$ east. It has a total land area of areas of $7,246 \mathrm{~km}^{2}$. The mean annual temperature of the state lies between $26^{\circ} \mathrm{C}$ and $29^{\circ} \mathrm{C}$ and average sunshine of about 1,450 hours per year. The mean annual rainfall ranges from $2,000 \mathrm{~mm}$ to $3,000 \mathrm{~mm}$, depending on the area. Akwa Ibom State has a population of about 3,902,051 [19]. The state is basically an agrarian society where crops like maize, okra, cassava, pineapple, tomato, yam and rice are cultivated in large quantities.

\subsection{Source of Data}

Secondary data were used in this study. The data came from the quarterly publication of the Akwa Ibom State Agricultural Development Programme (AKADEP). It consisted of the average monthly retailed price in Naira per kilogram of fresh tomato and pineapple from sampled markets in rural and urban areas of Akwa Ibom State. The study period covered January 2005 to September 2013. A total of 105 weeks' retailed average monthly prices $(\mathrm{N} / \mathrm{Kg})$ of fresh tomato and pineapple from rural and urban markets were used in the study.

\subsection{Analytical Techniques}

The study applied series of statistical and econometric techniques to test for the relationship between rural and urban prices of tomato and pineapple in the study area. The tests 
applied include; the trend analysis, bi-variate correlation analysis, Granger causality tests, co-integration and Error Correction Model (ECM) as well as Index of Market Connection analysis. Each of the tests is explained as shown below:

\subsection{The Trend Analysis of Monthly Retailed Prices of Fresh Tomato and Pineapple in Rural and Urban Markets of Akwa Ibom State in Nigeria}

To investigate the nature of growth rate in prices of fresh tomato and pineapple in the study area, the exponential growth rate equation was specified as thus:

$$
\begin{aligned}
& P_{t}=b_{o} e^{b t} e^{u t} \\
& \log _{e} P_{t}=b_{0}+b_{1} t+U_{t}
\end{aligned}
$$

Where exponential growth rate $(r)$ is defined as $\left(e^{b 1}-1\right) * 100$; where "e" is 2.7183. The quadratic exponential trend equation was also used to test for the impact of increasing time on prices of fresh tomato and pineapple in the rural and urban markets of the study area. The quadratic exponential trend equation was specified as thus:

$$
\log _{e} P_{t}=b_{o}+b_{1} t_{1}+b_{2} t_{2}^{2}+u_{t}
$$

If $b_{2}>0$; the variable investigated had accelerated growth rate: when $b_{2}<0$; the variable has decelerated growth rate over time. In this study, " $\mathrm{P}_{\mathrm{t}}$ " was represented by:

$$
\begin{gathered}
F T_{r t}=\text { monthly Price of fresh tomato in rural market } \\
F T_{u t}=\text { monthly Price of fresh tomato in Urban market } \\
P N_{r t}=\text { monthly Price of pineapple in rural market } \\
P N_{u t}=\text { monthly Price of pineapple in urban market }
\end{gathered}
$$

$\mathrm{t}=$ time trend $(1,2 \ldots 105)$. Note prices are in nominal unit; and measured in Naira/Kilogram.

The exponential growth rate equation was adopted in this study to investigate the growth in prices of fresh tomato and pineapple because, several literature have supported continuous inflated prices of agricultural commodities for some years in Nigeria [2, 11, 24, 5].

\subsection{Pearson Correlation Matrix of Average Monthly Retailed Prices of fresh tomato and pineapple in Rural and Urban Markets of Akwa Ibom State in Nigeria}

To test for the symmetrical and linear relationship between rural and urban prices of tomato and pineapple in Akwa Ibom State, the Pearson correlation coefficients were estimated. The formula is as described below:

$$
P_{r}=\frac{n \sum F T_{r t} F T_{u t}-\left(\sum F T_{r t}\right)\left(\sum F T_{u t}\right)}{\sqrt{\left\{n \sum F T_{r t}^{2}-\left(\sum F T_{r t}\right)^{2}\right\}\left\{\sum F T_{u t}^{2}-\left(\sum F T_{u t}\right)^{2}\right\}}}
$$

The "Pr" is the correlation coefficient between urban and rural market prices of fresh tomato and pineapple in the study area. A significant relationship between the considered variables suggests perfect price transmission or the presence of market integration between the two markets; while insignificant association suggests otherwise.

\subsection{Bilateral Granger Causality Test on Average Monthly Retailed Prices of Fresh Tomato and Pineapple in the Rural and Urban Markets of Akwa Ibom State in Nigeria}

The Granger causality test is a statistical hypothesis test for determining whether one time series is useful in forecasting another. A time series $X$ is said to Granger-cause $Y$ if it can be shown, usually through a series of t-tests and Ftest on lagged values of $X$ (and with lagged values of $Y$ also included), that those $X$ values provide statistically significant information about future values of $Y$ [16]. If a time series is a stationary process, the test is performed using the level values of two (or more) variables. If the variables are non-stationary, then the test is done using first (or higher) differences. To determine the number of lags (and to control for serial correlations) in a model, the Akaike, Schwarz or Hannan-Quinn information criteria are generally applied [8]. In this study, the bilateral Granger Causality tests were conducted on the average monthly retailed prices of fresh tomato and pineapple in urban and rural markets of Akwa Ibom State, southern Nigeria. The primary model in Vector Autoregressive Regression forms are represented as thus:

$$
\begin{aligned}
& \left\{\begin{array}{l}
\Delta L n F T_{r t}=\beta_{0}+\beta_{1} \sum_{i=1}^{n} \Delta L n F T_{r t-1}+\beta_{2} \sum_{i=1}^{n} \Delta L n F T_{u t-1}+\varepsilon_{1 t} \ldots .(5) \\
\Delta L n F T_{u t}=\delta_{0}+\delta_{1} \sum_{i=1}^{n} \Delta L n F T_{u t-1}+\delta_{2} \sum_{i=1}^{n} \Delta L n F T_{r t-1}+\varepsilon_{2 t} \ldots(6)
\end{array}\right\} \\
& \left\{\begin{array}{l}
\Delta L n P N_{r t}=\gamma_{0}+\gamma_{1} \sum_{i=1}^{n} L n P N_{r t-1}+\gamma_{2} \sum_{i=1}^{n} \Delta L n P N_{u t-1}+\varepsilon_{3 t} \ldots(7) \\
\Delta L n P N_{u t}=\alpha_{0}+\alpha_{1} \sum_{i=1}^{n} \Delta L n P N_{u t-1}+\alpha_{2} \sum_{i=1}^{n} \Delta L n P N_{r t-1}+\varepsilon_{4 t} \ldots(8)
\end{array}\right\}
\end{aligned}
$$

There is bilateral Granger causality from urban markets to rural market of fresh tomato, if $\beta_{2} \neq 0$ and $\delta_{2}=0$. The market, which Granger-causes the other is tagged the exogenous market or the lead market. Market price exogeneity can be weak or strong. According to Hendry [17] the weak exogeneity occurs when the marginal distribution of $P_{1 t-1}$ is independent of the joint distribution of both $P_{1 t-1}$ and $P_{2 t-1}$. On the other hand, strong exogeneity occurs when there is no statistically significant Granger-causality from the other variable. If we have two spatial prices, $P_{1 t-1}$ and $P_{2 t-1}$, the price $P_{1 t-1}$ is weakly exogenous to $P_{2 t-1}$ if $P_{1 t-1}$ is tested to be weakly exogenous and $P_{2 t-1}$ is not weakly exogenous to $P_{1 t-1}$. This implies that $P_{1 t-1}$ is causing $P_{2 t-1}$ to change and not vice-versa [9]. Similarly, there is Granger causality from the rural market price to urban market price of fresh tomato if $\beta_{2}=0$ and $\delta_{2} \neq 0$. The causality is considered as mutual or bidirectional if $\beta_{2} \neq 0$ and $\delta_{2} \neq 0$. Finally, there is no link between monthly price of fresh tomato in rural markets and urban markets if $\beta_{2}=0$ and $\delta_{2}=0$. The same interpretations follow for equations 7 and 8 for pineapple. The variables are as defined previously in equation (3). A bidirectional Granger causality test indicates the presence of perfect price 
transmission between prices of rural and urban markets for fresh tomato and pineapple in the study area.

\subsection{Co- Integration Test for Retailed Prices of Fresh Tomato and Pineapple in the Rural and Urban Markets of Akwa Ibom State in Nigeria}

If the geographically separated markets are co-integrated, then there exists an equilibrium or long run relationship among these markets $[14,28,13]$. The study applied the Engle and Granger two-step technique and Johansen co-integration approach to examine the co-integration relationships between rural and urban market prices of fresh tomato and pineapple in the study area. If two prices $\left(F T_{r t}\right.$ and $\left.F T_{u t}\right)$ are perfectly integrated, then $\gamma_{1}=$ 1 in equation 9. In this case, price changes in rural market $\left(F T_{r t}\right)$ are fully reflected in the urban $\left(F T_{u t}\right)$ market. When $\gamma_{1} \neq 1\left(\right.$ i.e. $\gamma_{1} 1$ or $\left.\gamma_{1} 1\right)$, then the degree of integration needs to be determined by investigating the variance of $\gamma_{1}$ from the threshold mark of 1 . Following the law of one price, the time dependent rural price equation for fresh tomato and pineapple is given as follows:

$$
\begin{aligned}
& \operatorname{LnFT}_{r t}=\gamma_{0}+\gamma_{1} \sum_{i=1}^{n} \operatorname{LnFT}_{u t}+U_{1 t} \\
& \operatorname{LnPN}_{r t}=\varphi_{0}+\varphi_{1} \sum_{i=1}^{n} \operatorname{LnPN}_{u t}+U_{2 t}
\end{aligned}
$$

Also, the urban price equation of fresh tomato and pineapple was specified in the similar manner. Following the Granger Representation Theorem, we specify the error correction model (ECM) for the co-integrating series in the study. The general specification of the ECM that was estimated for the rural price equation for fresh tomato and pineapple in the study area is shown below:

$$
\begin{aligned}
\Delta \mathrm{LnFT}_{r t}=\gamma_{0}+\gamma_{1} & \sum_{i=1}^{n} \Delta \operatorname{LnFT} T_{r t-1}+\gamma_{2} \sum_{i=1}^{n} \Delta \mathrm{LnFT}_{u t} \\
& +\gamma_{3} \sum_{i=1}^{n} \Delta \mathrm{LnFT}_{u t-i}+\gamma_{4} E_{C M} M_{t-1} \\
& +U_{1 t}
\end{aligned}
$$

$$
\begin{aligned}
\Delta \mathrm{LnPN}_{r t}=\vartheta_{0}+ & \vartheta_{1} \sum_{i=1}^{n} \Delta L n P N_{r t-1}+\vartheta_{2} \sum_{i=1}^{n} L n \Delta P N_{u t} \\
& +\vartheta_{3} \sum_{i=1}^{n} L n \Delta P N_{u t-i}+\vartheta_{4} E C M_{t-1} \\
& +U_{2 t}
\end{aligned}
$$

In this study, these equation series were replicated for the urban price of fresh tomato and pineapple respectively. The specified variables are as defined previously in equation (3), and the coefficient $\left(\gamma_{4}\right)$ and $\left(\vartheta_{4}\right)$ of the $\operatorname{ECM}_{t-1}\left(-1<\gamma_{4}, \vartheta_{4}<\right.$ $0)$ measures the deviations from the long-run equilibrium in period $(t-1))$ in both $\mathrm{FT}_{r t}$ and $\mathrm{PN}_{r t}$. The specification of equation 11 and 12 was to test for the short run market integration and determine the adjustment coefficient of
$\mathrm{FT}_{r t}$ and $\mathrm{PN}_{r t}$ to equilibrium level in the long run when there is exogenous shock in the system. This exercise was also done on the urban prices of fresh tomato and pineapple (i.e. $\mathrm{FT}_{u t}$ and $\mathrm{PN}_{u t}$ ).

\subsection{Index of Market Connection (IMC)}

The index of market connection (IMC) was used to measure the degree of short run price transmission or price relationship between integrated markets. Following Oladapo and Momoh, [23] technique, the relationship between the fresh tomato and pineapple in the rural and urban market is given by the equations below:

$$
\begin{gathered}
F T_{r t}=\delta_{0}+\delta_{1} F T_{r t-1}+\delta_{2}\left(F T_{u t}-F T_{u t-1}\right)+\delta_{3} F T_{u t-1}+\varepsilon_{1 t} \\
P N_{r t}=\varphi_{0}+\varphi_{1} P N_{r t-1}+\varphi_{2}\left(P N_{u t}-P N_{u t-1}\right)+\varphi_{3} P N_{u t-1}+\varepsilon_{2 t}(14)
\end{gathered}
$$

Then IMC $=\delta_{1} / \delta_{3}$ for fresh tomato and $=\varphi_{1} / \varphi_{3}$ for Pineapple. Note, when the estimated IMC $<1$, it implies high short run market Integration; IMC $>1$ implies low short run market Integration; IMC $=\infty$ implies no market integration; $\mathrm{IMC}=1$ high or low short run market integration. Other variables are as defined in equations 3 .

\section{Results and Discussions}

\subsection{Augmented Dicker Fuller and Augmented Dicker Fuller-GLS Unit Root Test Results}

The stationary status of prices of fresh tomato and pineapple was examined by the unit root tests. The Augmented Dicker Fuller (ADF) and Augmented Dicker Fuller -GLS unit root tests were used to ascertain the stationary of the specified price variables. The result of the tests is presented in Table 1 and 2. The result showed that, prices of fresh tomato in the rural and urban markets were non-stationary at levels but stationary (at 1\% significance

\begin{tabular}{|c|c|c|c|c|c|c|}
\hline \multirow{3}{*}{$\begin{array}{l}\text { Logged } \\
\text { Variables }\end{array}$} & \multicolumn{6}{|c|}{ Augmented Dicker Fuller Test for unit root } \\
\hline & \multicolumn{3}{|c|}{ With Constant } & \multicolumn{3}{|c|}{ Constant and Trend } \\
\hline & Level & $\begin{array}{l}\text { 1st } \\
\text { diff. }\end{array}$ & OT & Level & $\begin{array}{r}\text { 1st } \\
\text { diff. }\end{array}$ & OT \\
\hline$L n F T_{r t}$ & -2.778 & $-14.61 *$ & $1(1)$ & $-4.782 *$ & - & $1(0)$ \\
\hline $\operatorname{LnFT}_{u t}$ & -3.360 & $-14.72 *$ & $1(1)$ & $-5.982 *$ & - & $1(0)$ \\
\hline$L n P N_{r t}$ & $-4.712 *$ & - & $1(0)$ & $-7.735^{*}$ & - & $1(0)$ \\
\hline $\operatorname{LnPN}_{u t}$ & $-4.357 *$ & - & $1(0)$ & $-7.321 *$ & - & $1(0)$ \\
\hline $1 \%(\mathrm{CV})$ & -3.49 & -3.50 & & -4.05 & -4.50 & \\
\hline
\end{tabular}
level) at first difference for the ADF and ADF-GLS equations that contain constant only. On the other hand, prices of pineapple in the rural and urban markets were stationary at level using the two unit root equations. However, when the two unit root equations were specified to include constant and deterministic trend, prices of fresh tomato and pineapple were stationary at levels.

Table 1. Result of the Augmented Dicker Fuller unit root test for prices of fresh tomato and pineapple used in the analysis.

Note: OT means order of integration. Critical value (CV) is defined at $1 \%$ significant level and asterisk * represent 1\% significance level. Variables are as defined in equation 3 
Table 2. Result of the Augmented Dicker Fuller - GLS unit root tests for prices of fresh Tomato and Pineapple used in the analysis.

\begin{tabular}{lcccccc}
\hline \multirow{2}{*}{$\begin{array}{l}\text { Logged } \\
\text { Variables }\end{array}$} & \multicolumn{3}{c}{ Augmented Dicker Fuller - GLS Test for unit root } \\
& Level & 1st diff. & OT & Level & $\begin{array}{c}\text { 1st } \\
\text { diff. }\end{array}$ & OT \\
\hline LnFT $_{r t}$ & -2.121 & $-11.325^{*}$ & $1(1)$ & $-4.749^{*}$ & - & $1(0)$ \\
$L n F T_{u t}$ & -2.260 & $-10.791^{*}$ & $1(1)$ & $-5.948^{*}$ & - & $1(0)$ \\
$L_{n} N_{r t}$ & $-3.809^{*}$ & - & $1(0)$ & $-7.731^{*}$ & - & $1(0)$ \\
$L n P N_{u t}$ & $-3.454^{*}$ & - & $1(0)$ & $-7.308^{*}$ & - & $1(0)$ \\
\hline
\end{tabular}

Note: OT means order of integration. Critical value (CV) is defined at $1 \%$ significant level and asterisk * represent $1 \%$ significance level. Variables are as defined in equation 3 .

The result implies that, prices of fresh tomato cannot be specified at their levels without the risk of obtaining spurious regression. Also, the result indicates that, there is need to test for the presence of co-integration and short run relationship between the rural and urban prices of fresh tomato in the study area. Despite the stationary status of pineapple prices in the rural and urban markets, the study also investigated the short run properties by subjecting the price variables to further empirical tests. The nature of the stationary of the specified price variables is similar to the research results reported by several researchers on different food stuffs in Nigeria. They include; Okoh and Egbon [22], Ojiako et al., [21] and Akpan et al., [4].

\subsection{Descriptive Analysis of Monthly Prices of Fresh Tomato and Pineapple in Akwa Ibom State (from January 2005 to June 2013)}

The descriptive statistics of the price variable used in the analyses is shown in Table 3. The average price of fresh tomato in rural and urban markets of Akwa Ibom State was $\$ 321.15 / \mathrm{kg}$ and $\$ 244.41 / \mathrm{kg}$ respectively. Also, the average price of Pineapple was $\$ 121.84 / \mathrm{kg}$ and $\$ 139.57 / \mathrm{kg}$ in rural and urban markets respectively. These findings revealed that, there might be significant deviations or differences between rural and urban price of fresh tomato and Pineapple in the study area. The standard deviations of 90.25 and 90.87 in prices of fresh tomato in the rural and urban markets respectively, indicates that, changes in both prices assume similar patterns during the study period. In addition, the coefficient of variability in price of fresh tomato in the rural and urban markets was $39.00 \%$ and $37.20 \%$ respectively.

Table 3. Descriptive Statistic of Price variables used in the model.

\begin{tabular}{lcccc}
\hline & \multicolumn{2}{c}{ Fresh tomato Price } & \multicolumn{2}{c}{ Pineapple Price } \\
Pural & Urban & Rural & Urban \\
& Market & Market & Market & Market \\
(N/Kg) & (N/Kg) & (N/Kg) & (N/Kg) \\
\hline Mean & 231.15 & 244.41 & 121.84 & 139.57 \\
Median & 217.00 & 241.02 & 120.00 & 137.01 \\
Minimum & 77.400 & 80.600 & 62.870 & 73.66 \\
Maximum & 480.54 & 507.94 & 267.08 & 250.00 \\
Std. deviation & 90.250 & 90.870 & 40.675 & 45.620 \\
Co.Variation & 0.390 & 0.372 & 0.334 & 0.327 \\
Skewness & 0.517 & 0.366 & 0.877 & 0.452 \\
Kurtosis & 0.158 & -0.127 & 1.111 & -0.756 \\
AGR (\%) & 3.907 & 4.418 & 4.192 & 3.822 \\
\hline
\end{tabular}

Note: Computed by authors, and prices are expressed in nominal terms. AGR means average growth rate.

For Pineapple, it stood at $33.40 \%$ and $32.70 \%$ for rural and urban markets respectively. The finding showed that, rural prices of fresh tomato and Pineapple exhibited higher variations compared to their respective urban prices. Furthermore, the average linear growth rate in the price of fresh tomato in the rural and urban markets were $3.907 \%$ and $4.418 \%$ respectively. Similarly, the price of Pineapple grew at the rate of $4.192 \%$ and $3.822 \%$ in the rural and urban markets respectively.

\subsection{Exponential Trend Analysis of Prices of Fresh Tomato and Pineapple in Rural and Urban Markets of Akwa Ibom State (2005 to 2013)}

The exponential trend equations for each of the price variables specified in equation 3 is presented in Table 4 . The estimated regression result for each of the price variables is followed by the calculated exponential growth rate and the conclusion derived from the respective long run exponential trend equation. The result revealed that, trends in prices of fresh tomato and pineapple in rural and urban markets showed positive significant relationship with time in the study area.

Table 4. Exponential Trend Analysis of Monthly Average Prices of fresh tomato and Pineapple in Rural and Urban Markets in Akwa Ibom State (2005 to 2013).

\begin{tabular}{|c|c|c|c|c|}
\hline Variables & $\operatorname{LnFT}_{r t}$ & $\operatorname{LnFT}_{u t}$ & $\operatorname{LnPN}_{r t}$ & $\operatorname{LnPN}_{u t}$ \\
\hline Constant & $4.78(90.66)^{*}$ & $4.87(97.82)^{*}$ & $4.34(97.44)^{*}$ & $4.46(102.7)^{*}$ \\
\hline Time & $0.012(12.66)^{*}$ & $0.011(12.86)^{*}$ & $0.008(10.60)^{*}$ & $0.008(11.31)^{*}$ \\
\hline F- cal. & $160.38 *$ & $165.41 *$ & $112.40 *$ & $127.94 *$ \\
\hline R-square & 0.609 & 0.616 & 0.522 & 0.554 \\
\hline EGR (\%) & 1.099 & 1.054 & 0.776 & 0.808 \\
\hline \multicolumn{5}{|c|}{ Nature of Growth Rate } \\
\hline Constant & $4.808(59.83)^{*}$ & $4.83(63.76)^{*}$ & $4.19(64.35)^{*}$ & $4.33(67.57)^{*}$ \\
\hline Time $\left(b_{1}\right)$ & $0.009(2.68) * *$ & $0.013(3.81)^{*}$ & $0.016(5.61)^{*}$ & $0.015(5.41)^{*}$ \\
\hline Time $\left(b_{2}\right)$ & $1.58 \mathrm{e}-05(0.46)$ & $-2.0 \mathrm{e}-05(-0.66)$ & $-7.72 \mathrm{e}-05(-2.97)^{*}$ & $-6.7 e-05(-2.61)^{*}$ \\
\hline F- cal. & $79.68 *$ & $82.462 *$ & $64.903^{*}$ & $70.968 *$ \\
\hline R-square & 0.609 & 0.618 & 0.559 & 0.559 \\
\hline Inference & No effect & No effect & Significant GR & Significant GR \\
\hline
\end{tabular}

Note: Values in bracket represent t-values. The asterisks *, and **represent $1 \%$, and $5 \%$ significance levels respectively. EGR means exponential growth rate $(\%)$, Variables are as defined in equation 3. 
This implies that, changes in price of fresh tomato and pineapple in the rural and urban markets is influenced by time variable. Prices of fresh tomato in the rural and urban market have exponential growth rate of $1.099 \%$ and $1.054 \%$ respectively. In the similar way, about $0.776 \%$ and $0.808 \%$ exponential growth rate was identified in the rural and urban prices of pineapple. These results suggest that, there are noticeably dispersions between prices of fresh tomato in rural and urban markets in the study area; whereas the dispersion was more conspicuous in prices of pineapple in the two spatial markets. The result suggests that, there is possibility of market integration between the rural and urban prices of fresh tomato and pineapple in the study area. The nature of exponential growth in each price variable investigated revealed that, over time the price of fresh tomato in rural and urban markets showed insignificant decrease.

On the other hand, prices of pineapple in the rural and urban markets exhibited significant negative relationships with increase in time. This implies that, the prices of pineapple in rural and urban markets witnessed significant marginal deceases over increase period of time. These results are in consonance with the research report of Amusa, [7] who asserted that, agricultural commodity prices experienced increase and fluctuations over time in Nigeria. Akpan et al., [4] also attested to this result on grain food stuffs in the southern Nigeria.
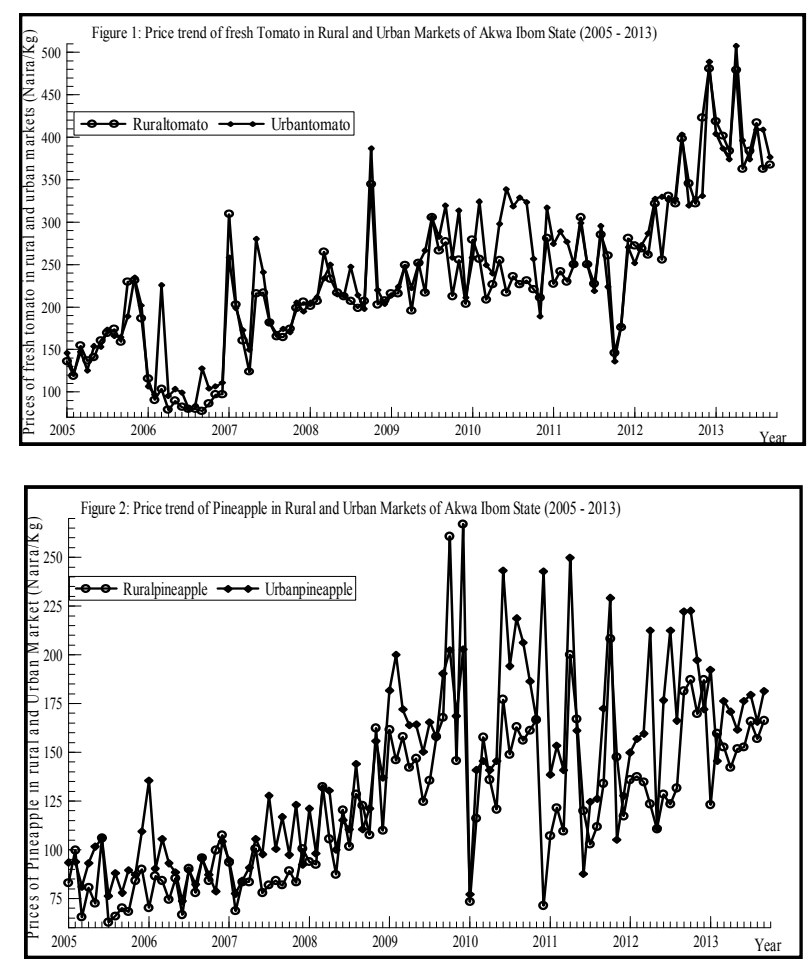

The graphically representation of the linear price trend in fresh tomato and pineapple from January 2005 to September 2013, is shown in figure 1 and 2 respectively. The price trends show undulated fluctuations throughout the study period. In figure 1, the rural and urban price of fresh tomato seems to move together in most part of the year. However, both prices exhibited similar pattern of fluctuations throughout the study period. The result implies that, the rural and urban prices of fresh tomato move together in the period of investigation. Similarly, in figure 2, the linear trend in price of pineapple in rural and urban markets of Akwa Ibom State showed undulated fluctuations during the period of investigation. There were conspicuous dispersions between the rural and urban price of pineapple from 2010 to 2013 in the study area. On average, it seems prices of fresh tomato and pineapple assume similar pattern of fluctuations in most part of the period under consideration. Following this nature of fluctuations in the price of fresh tomato and pineapple in the rural and urban markets; it is suggested that, there is a strong evidence of symmetric price transmission mechanism or market integration between the two prices.

\subsection{Pearson Correlation Matrix of Monthly Prices of Fresh Tomato and Pineapple (Expressed in $\mathrm{A} / \mathrm{Kg}$ ) in Rural and Urban Markets in Akwa Ibom State, Southern Nigeria}

The linear and symmetric relationship between the average monthly price of fresh tomato and pineapple in the rural and urban markets of Akwa Ibom State was captured by the Pearson correlation coefficient. Table 5 presents the correlation matrix of rural and urban prices of fresh tomato and pineapple from January 2005 to September 2013 in Akwa Ibom State, Southern Nigeria. The result indicates that, prices of fresh tomato and pineapple in the rural market have positive significant (at $1 \%$ probability level) linear relationship with their corresponding prices in the urban markets. This means that, the price of fresh tomato in the rural market has a strong linear relationship with its own price in urban market in the study area. The same result was also obtainable for the pineapple market in the study area. These results further provide strong support for the existence of price integration or good price transmission mechanism between the rural and urban markets for vegetables (i.e. fresh tomato and pineapple) in Akwa Ibom State in southern Nigeria. This result implies that, factors that influence price of fresh tomato and pineapple marketing in the rural markets are similar to those in urban markets in the study area.

Table 5. Pearson correlation matrix for prices of fresh tomato and Pineapple in Rural and Urban Markets in Akwa Ibom State (2005 - 2013).

\begin{tabular}{lrlll}
\hline Variables & $\boldsymbol{F T}_{\boldsymbol{r t}}$ & \multicolumn{1}{c}{$\boldsymbol{F T _ { \boldsymbol { u t } }}$} & $\boldsymbol{P N}_{\boldsymbol{r t}}$ & \multicolumn{1}{c}{$\boldsymbol{P \boldsymbol { N } _ { \boldsymbol { u t } }}$} \\
\hline$F T_{r t}$ & 1.000 & $0.936^{*}$ & $0.481^{*}$ & $0.561^{*}$ \\
$F T_{r t}$ & & 1.000 & $0.506^{*}$ & $0.616^{*}$ \\
$P N_{u t}$ & & & 1.000 & $0.785^{*}$ \\
$P N_{u t}$ & & & & 1.000 \\
\hline
\end{tabular}

Note: variables are as expressed in equation $3 . *$ means statistically significant at $1 \%$ probability level; while values are bi-variate correlation coefficients. 


\subsection{Bilateral Granger Causality Test for Prices of Fresh Tomato and Pineapple in Rural and Urban Markets in Akwa Ibom State (2005 - 2013)}

The causality relationship between the rural and urban prices of fresh tomato and Pineapple was tested in Akwa Ibom State. The result of the analysis is presented in Table 7. The result in Table 6 shows the optimal lag period used in the causality equation specified in equations 5 to 8 . The asterisks below indicate the best (that is, minimized) values of the respective information criteria, $\mathrm{AIC}=$ Akaike criterion, $\mathrm{BIC}=$ Schwarz Bayesian criterion and $\mathrm{HQC}=$ Hannan-Quinn criterion.

Table 6. The optimal Lag length for the causality equation

\begin{tabular}{llllll}
\hline Lag & Loglikelihood & P(LR) & AIC & BIC & HQC \\
\hline 1 & 125.769 & - & $-2.094^{*}$ & $-1.577^{*}$ & $-1.885^{*}$ \\
2 & 137.518 & 0.101 & -2.010 & -1.078 & -1.633 \\
3 & 145.384 & 0.471 & -1.849 & -0.503 & -1.304 \\
4 & 157.359 & 0.091 & -1.769 & -0.009 & -1.057 \\
\hline
\end{tabular}

Source: From data analysis.

The corresponding lag length indicates the best lag length for generating a more parsimonious causality equation for the specify price series. The result of the exercise indicated that lag 1 was more appropriate for the causality equations. This implies that the causality equations generated were done by using one period lagged of the variables involved. The estimated bilateral Granger causality estimates are presented in Table 7 .

Table 7. The vector autoregressive regression Granger causality estimates.

\begin{tabular}{|c|c|c|c|c|c|}
\hline Hypotheses & Lag & $\begin{array}{c}\text { Sample } \\
\text { size }\end{array}$ & F-Statistic & Prob. & Decision \\
\hline $\begin{array}{l}\Delta L n F T_{r t} \\
\rightarrow \Delta L n F T_{u t}\end{array}$ & 1 & 103 & 6.9398 & $0.000 * * *$ & Rejected \\
\hline $\begin{array}{l}\Delta L n F T_{u t} \rightarrow \\
\Delta L n F T_{r t}\end{array}$ & 1 & 103 & 4.6535 & $0.012 * *$ & Rejected \\
\hline $\begin{array}{l}\operatorname{Ln} P N_{r t} \\
\rightarrow L n P N_{u t}\end{array}$ & 1 & 104 & 47.668 & $0.000 * * *$ & Rejected \\
\hline $\begin{array}{l}L n P N_{u t} \rightarrow \\
L n P N_{r t}\end{array}$ & 1 & 104 & 49.775 & $0.000 * * *$ & Rejected \\
\hline
\end{tabular}

Note: Variables are as defined in equation $3 . \rightarrow$ means does not Granger cause.

The result presented in Table 7 suggests that, there is a bi-directional Granger causality association between the urban price and rural price of fresh tomato and pineapple from January 2005 to September 2013 in the study area. It means that, rural price of fresh tomato and pineapple is strongly endogenous to its respective urban price. The result also means that, the causality runs from urban market to rural market and vice versa. Alternatively, the result implies that, urban price of fresh tomato and Pineapple affected positively on their respective rural prices; and in the same manner the rural price of fresh tomato and pineapple influences their respective urban prices. In the similar way, the previous price in urban market significantly predicted the current price in the rural market for fresh tomato and pineapple in the study area. The presence of the bi-directional Granger Causality between the rural and urban prices of fresh tomato and pineapple indicated that, there is a perfect price transmission mechanism or market integration between the two markets in the study area. Following this result, the flow of markets information between the rural and urban markets concerning the fresh tomato and pineapple could be described as symmetric. The result further suggested that, the rural and urban prices of fresh tomato and pineapple might be tight together in the long run and the effect of transfer cost not significant. Based on the magnitude of the diagnostic statistics, it appears that, the rural market is the lead or the driving market in the short run for fresh tomato and urban market for Pineapple marketing in the state. This result can be attributed to the fact that, the bulk quantity of Pineapple consumed in the study area is brought from the neigbouring states. This commodity is mostly haboured in the urban markets for onwards distribution to other spatial markets. The result for the fresh tomato perhaps suggests the increasing importance of domestic production in the study area. In addition, the result suggests probably high degree of competitive market structure and strong endogeneity in the rural and urban prices of fresh tomato and Pineapple markets in the region. This result corroborates reports of Okoh and Egbon [22] and Adeoye et al., [3] for different food stuffs in western Nigeria. Akpan et al., [4] also confirm the similar relationship in grains in southern Nigeria.

\subsection{The Engle Granger Two - Step and Johansen Co-Integration Test on Prices of Fresh Tomato and Pineapple in the Rural and Urban Markets of Akwa Ibom State, Nigeria}

The result of the Engle and Granger two-step technique of co-integration regression tests for the residuals (ECM) generated in the long run equations is presented in the lower portion of Table 9 and Table 10 . The results show that at $1 \%$ probability level of significance, the ADF test for the residual is significant (i.e. the estimated tau test from the residuals is greater than the critical tau value). Thus the Engle-Granger co-integration tests reject the null hypothesis of no co-integration for the four specified equations. Hence, there exist long run equilibria relationships between the rural and urban prices of fresh tomato and pineapple in the study area. Following the above results, the evidence of the long-run equilibria relationships between the rural and urban prices of fresh tomato and pineapple was strong, hence there was need to verify the result by conducting Johansen cointegration test. Table 8, presents results of the Johansen test meant to examine the long-run relationships between the rural and urban price of fresh tomato and pineapple. The null hypothesis of no cointegration between the rural and urban price of fresh tomato and pineapple were rejected at the conventional levels for both Trace and Max-Eingen statistics. There was no conflict between the Trace and Max-Eingen statistics, so the Johansen approach further confirms at least 
one cointegration equation between the rural and urban price of fresh tomato and pineapple in the study area.

Table 8. Results of Johansen Cointegration Test.

\begin{tabular}{ccccc}
\hline Markets & $\begin{array}{c}\text { Hypothes } \\
\text { es }\end{array}$ & Trace Statistics & $\begin{array}{c}\text { Hypoth } \\
\text { eses }\end{array}$ & $\begin{array}{c}\text { Max.-Eigen } \\
\text { Statistics }\end{array}$ \\
\hline \multirow{2}{*}{$\mathrm{FT}_{\mathrm{rt}} \rightarrow \mathrm{FT}_{\mathrm{ut}}$} & $\mathrm{r}=0$ & $14.544(0.069)^{*}$ & $\mathrm{r}=0$ & $13.709(0.061)^{*}$ \\
& $\mathrm{r} \leq 1$ & $0.835(0.361)$ & $\mathrm{r}=1$ & $0.835(0.361)$ \\
& & & & \\
$\mathrm{PN}_{\mathrm{rt}} \rightarrow \mathrm{PN}_{\mathrm{ut}}$ & $\mathrm{r}=0$ & $15.905(0.034)^{*}$ & $\mathrm{r}=0$ & $13.137(0.075)^{*}$ \\
& $\mathrm{r} \leq 1$ & $2.768(0.096)^{*}$ & $\mathrm{r}=1$ & $2.768(0.096)^{*}$ \\
\hline
\end{tabular}

Source: Computed by authors. Trend assumption: linear deterministic trend. " $r$ " indicates the number of co-integrating equation. Asterisk * represents rejection of the null hypothesis at $10 \%$ significance level. P-values derived from Mackinnon-Haug-Michelis, (1999) methodology. Critical values for the trace test are 15.495 and 3.841 respectively; while critical values for the Maximum Eingenvalue test are 14.265 and 3.841 respectively.

\subsection{Regression Estimates for the Co-Integration Model and the Law of one Price (LOP) for Prices of Fresh Tomato and Pineapple in Rural and Urban Markets of Akwa Ibom State, Southern Nigeria}

The result in Table 9 and Table 10 present the regression estimates to test the co-integration and law of one price in fresh tomato and Pineapple markets in the study area. Results in Table 9 contain the rural and urban price equation estimates for the fresh tomato in the study area. The R-square for the fresh tomato equations is 0.89 . This implies that, about $89 \%$ of the total variability in the rural price of fresh tomato is explained by its respective urban prices. The result also applied to the urban price equation. The F-statistics for the two equations is significant at $1 \%$ probability level; thus confirming the significant of the estimated R-squares for the two equations. The result for the rural price of fresh tomato indicated that, the price transmission between the rural and urban markets exhibited near perfect long run integration. This is because; the integration coefficient (or inelastic coefficient) is approximately unity (i.e. 0.989 ). These results give a strong evidence of long run price integration between the rural and urban market prices of fresh tomato in the study area.

Table 9. Long run Relationships between prices of Fresh Tomato and Pineapple in Rural and Urban markets of Akwa Ibom State (2005 - 2013).

\begin{tabular}{llcl}
\hline Variable & $\begin{array}{l}\text { LnFTrt=fLnFTut } \\
\text { (Fresh Tomato) }\end{array}$ & Variable & $\begin{array}{l}\text { LnFTut= fLnFTrt } \\
\text { (Fresh Tomato) }\end{array}$ \\
\hline Constant & $-0.006(-0.032)$ & Constant & $0.610(3.620)^{*}$ \\
LnFt $_{u t}$ & $0.989(28.65)^{*}$ & LnFT $_{r t}$ & $0.898(28.65)^{*}$ \\
F-cal & $820.6511^{*}$ & F-cal & $820.657^{*}$ \\
$\mathrm{R}^{2}$ & 0.888 & $\mathrm{R}^{2}$ & 0.888 \\
DW- test & 1.321 & DW- test & 1.434 \\
ADF test for errors from above equations & \\
ECM & $-7.138 * * *$ & $-7.557 * * *$ & \\
\hline
\end{tabular}

Note: the equation for the ADF test include constant and trend. Critical value at $1 \%=-4.05$, Values in bracket represent t-values. The asterisk * represents $1 \%$ significance level. Variables are as defined in equation 3 .
The result for the urban price equation of tomato also shows a strong indication of the law of one price. However, the coefficient of the long run market integration (inelastic coefficient) was not approximately unity. This means that, the long run market integration coefficient for the urban price equation is weaker than the rural price equation. The magnitude of market integration coefficient for the fresh tomato suggests that, the urban price impact on the rural price is more relative to the rural price impact on urban price in the study area. Hence, the market integration in fresh tomato is stronger when market information flow from urban to rural markets compared to the reverse case in the study area. Similarly, results in Table 10 contain the rural and urban price equation estimates for Pineapple in the study area. The R-square value is 0.67 , and it implies that, about $67 \%$ of the total variability in the rural price of pineapple is explained by its respective urban prices. The same result applied to the urban price equation. The F-statistics for both equations is significant at $1 \%$ probability level; thus confirming the significant of the estimated R-square. The estimated rural price equation of pineapple indicated that, the price transmission between the rural and urban markets exhibited strong significant but not perfect long run integration. This is because; the integration coefficient (or inelastic coefficient) is far from unity (i.e. 0.809 ). These results give a good evidence of long run price integration between the rural and urban market prices of pineapple in the state. The result for the urban price equation of pineapple also revealed a good indication of the law of one price. However, the coefficient of the long run market integration (inelastic coefficient) was still far from unity.

Table 10. Long run Relationships in prices of fresh Tomato and Pineapple in Rural and Urban Markets of Akwa Ibom State (2005 - 2013).

\begin{tabular}{llll}
\hline Variable & $\begin{array}{l}\text { LnPNrt } \text { fLnPNut } \\
\text { (Pineapple) }\end{array}$ & Variable & $\begin{array}{l}\text { LnPNut }=\text { fLnPNrt } \\
\text { (Pineapple) }\end{array}$ \\
\hline Constant & $0.796(2.887)^{*}$ & Constant & $0.969(3.548)^{*}$ \\
LnPN $_{u t}$ & $0.8093(14.37)^{*}$ & $L^{*} P N_{r t}$ & $0.8251(14.37)^{*}$ \\
F-cal & $206.591^{*}$ & F-cal & $206.591^{*}$ \\
$\mathrm{R}^{2}$ & 0.667 & $\mathrm{R}^{2}$ & 0.667 \\
DW- test & 1.857 & $\mathrm{DW}$-test & 1.764 \\
ADF test for errors from above equations & \\
ECM & $-8.523^{*}$ & & $-9.671^{*}$ \\
\hline
\end{tabular}

Note: the equation for the ADF test include constant. Critical value at $1 \%=$ -3.50 , Values in bracket represent t-values. The asterisk * represents $1 \%$ significance level. Variables are as defined in equation 3.

Comparing the two price equations for pineapple, the long run market integration coefficient for the urban price equation is stronger than the rural price equation. Based on the magnitude of market integration coefficient for the rural and urban price of pineapple, it is suggested that, the rural price impact on the urban price is more relative to the reverse situation in the study area. Hence, the long run market integration in pineapple is stronger when market information flow from the rural to urban markets compared 
to the opposite case. The result provided additional evidence that, the rural market is the driver in the marketing of pineapple in Akwa Ibom State. However, the result for the fresh tomato supported urban market leadership role contrary to the previous report.

\subsection{Error Correction Model of the price of fresh tomato and Pineapple in Rural and Urban markets in Akwa Ibom State (2005 - 2013)}

Table 11. ECM estimates for the rural and urban price of fresh tomato in Akwa Ibom State.

\begin{tabular}{|c|c|c|c|}
\hline \multicolumn{2}{|c|}{$\boldsymbol{L n F T}_{\boldsymbol{r t}}=f\left(\boldsymbol{L n F T}_{\boldsymbol{u}}\right)$} & \multicolumn{2}{|c|}{$\boldsymbol{L n} \boldsymbol{F} \boldsymbol{T}_{\boldsymbol{u t}}=f\left(\boldsymbol{L n} \boldsymbol{F} \boldsymbol{T}_{\boldsymbol{r t}}\right)$} \\
\hline Variable & $\begin{array}{l}\text { Coefficient and } \\
\text { t-test }\end{array}$ & Variable & $\begin{array}{l}\text { Coefficient and } \\
\text { t-test }\end{array}$ \\
\hline Constant & $0.003(0.240)$ & Constant & $0.002(0.13)$ \\
\hline$\Delta L n F T_{r t-1}$ & $-0.084(-0.82)$ & $\Delta L n F T_{u t-1}$ & $-0.034(-0.34)$ \\
\hline$\Delta L n F T_{u t}$ & $0.769(14.40)^{*}$ & $\Delta L n F T_{r t}$ & $0.856(14.29)^{*}$ \\
\hline$\Delta L n F T_{u t-1}$ & $0.013(0.14)$ & $\Delta L n F T_{r t-1}$ & $0.035(0.32)$ \\
\hline$E C M_{t-1}$ & $-0.507(-4.59)^{*}$ & $E C M_{t-1}$ & $-0.697(-5.77)^{*}$ \\
\hline \multicolumn{2}{|c|}{$\begin{array}{l}\mathrm{R}^{2}=0.708 ; \text { F-cal. }=59.31 * ; \mathrm{DW}= \\
1.97 ; \text { Log-likelihood }=68.80\end{array}$} & \multicolumn{2}{|c|}{$\begin{array}{l}\mathrm{R}^{2}=0.745 ; \text { F-cal. }=71.75^{*} ; \mathrm{DW}= \\
\text { 2.02; Log-likelihood }=63.93\end{array}$} \\
\hline
\end{tabular}

Note: Values in bracket represent t-values. The asterisk * represent $1 \%$ significance level. Variables are as defined in equation 3.

Table 12. ECM estimates for the rural and urban price of Pineapple.

\begin{tabular}{|c|c|c|c|}
\hline \multicolumn{2}{|c|}{$L n P N_{r t}=f\left(L n P N_{u t}\right)$} & \multicolumn{2}{|c|}{$\operatorname{LnPN}_{u t}=f\left(\operatorname{LnPN}_{r t}\right)$} \\
\hline Variable & $\begin{array}{l}\text { Coefficient and } \\
\text { t-test }\end{array}$ & Variable & $\begin{array}{l}\text { Coefficient and } \\
\text { t-test }\end{array}$ \\
\hline Constant & $0.002(0.10)$ & Constant & $0.005(0.26)$ \\
\hline$\Delta L n P N_{r t-1}$ & $-0.234(-2.45)^{* *}$ & $\Delta L n P N_{u t-1}$ & $-0.235(-2.31)^{* *}$ \\
\hline$\Delta \operatorname{Ln} L n P N_{u t}$ & $0.557(7.24)^{* * *}$ & $\Delta \operatorname{Ln} \operatorname{Ln} P N_{r t}$ & $0.600(7.61)^{* * *}$ \\
\hline$\Delta \operatorname{Ln} \operatorname{LnPN}_{u t-1}$ & $0.121(1.21)$ & $\Delta \operatorname{Ln} \operatorname{Ln} P N_{r t-1}$ & $0.069(0.74)$ \\
\hline$E C M_{t-1}$ & $-0.688(-5.4)^{* * *}$ & $\mathrm{ECM}_{\mathrm{t}-1}$ & $-0.605(-4.7)^{* * *}$ \\
\hline \multicolumn{2}{|c|}{$\begin{array}{l}\mathrm{R}^{2}=0.603 ; \text { F-cal. }=37.143 * * * ; \\
\mathrm{DW}=2.013 ; \text { Log-likelihood }= \\
34.098\end{array}$} & \multicolumn{2}{|c|}{$\begin{array}{l}\mathrm{R}^{2}=0.541 ; \text { F-cal. }=28.710 * * * \\
\mathrm{DW}=2.105 ; \text { Log-likelihood }= \\
32.707\end{array}$} \\
\hline
\end{tabular}

Note: Values in bracket represent t-values. The asterisk *** represent $1 \%$ significance level. Variables are as defined in equation 3.

The presence of the co-integration among the specified price variables demanded the specification of the Error Correction Model (ECM). Table 11 contains estimates of ECM generated from the rural and urban price of fresh tomato; while Table 12 contains estimates of the ECM generated from the rural and urban price of pineapple. For the rural and urban price equation of fresh tomato, the coefficient of the error correction terms is negative and statistically significant at $1 \%$ probability level respectively. The result validates the existence of the long-run equilibrium relationships between the rural and urban market prices of fresh tomato in the study area. The result further implies that, the rural and urban prices of fresh tomato are sensitive to departure from their equilibrium levels in the previous periods. The slope coefficients of the error correction term for the rural $(-0.507)$ and urban $(-0.697)$ price equation represents the speed of adjustment of respective price equation and also is consistent with the hypothesis of convergence towards the long-run equilibrium once the price equation is shocked.

The diagnostic tests for the ECM model of fresh tomato price equation revealed the $\mathrm{R}^{2}$ values of 0.708 and 0.74 for the rural and urban price equation respectively. This means that the specified explanatory variables explained about $70.85 \%$ and $74.00 \%$ of the adjusted total variations in the rural and urban price of fresh tomato respectively in the study area. The F-statistics for the two equations are significant at $1 \%$ probability level, indicating that the two $\mathrm{R}^{2}$ are significant and this implies that, the ECM of rural and urban price of fresh tomato has goodness of fit. The auto-correlation was not a serious problem in the two equations. The result revealed that, about $50.70 \%$ and $69.70 \%$ of the rural and urban price adjustments of fresh tomato take place respectively within every month due to exogenous shock. That is, it will take about 7 weeks 6 days for the rural price of fresh tomato; and 5 weeks 5 days for the urban price of fresh tomato; to fully adjust to the equilibrium position in the long run due to shock in the marketing system. The result suggests that, the urban price of fresh tomato adjusted faster than the rural price. By implication, movements in the rural price of fresh tomato is significantly detected by it respective urban price. Given the magnitude of adjustment, it seems the adjustment rate in the rural and urban price of fresh tomato in the study area is not instantaneous. It is suggested that, the rural price of fresh tomato is strongly endogenous to its urban price. The result is in consonance with the research report of Okoh and Egbon [22] and Akpan et al., [4] on different food stuffs in Nigeria.

For the Pineapple market, the slope coefficient of the error correction term for the rural (-0.688) and urban $(-0.605)$ price of pineapple is negative and statistically significant at $1 \%$ probability level. The coefficient of the error correction terms shows the speed of convergence to the long run equilibrium as a result of shock in the pineapple price equations. This indicates that, any disequilibrium in the long run of either rural or urban price of pineapple would be corrected in the short run. The significant value of the error correction term implies that, the urban price of pineapple will always react to bring stability in the rural price whenever there is significant variation in the rural price and vice versa. The result revealed that, about $68.80 \%$ and $60.50 \%$ of the rural and urban price adjustments take place respectively within every month due to exogenous shock in the system. That is, it will take about 5 weeks 5 days and 6 weeks 4 days for the rural and urban price of pineapple respectively, to fully adjust to equilibrium position in the long run due to shock in the system. The result revealed that, the rural price of pineapple adjusted faster than the rural price. By implication, movements in the rural price of pineapple is significantly detected by it respective urban price. The 
diagnostic statistics derived from the ECM with respect to pineapple price revealed $\mathrm{R}^{2}$ values of 0.603 and 0.541 for the rural and urban price equation respectively. This means that, the explanatory variables contained in the pineapple price equation explain about $60.30 \%$ and $54.10 \%$ of the total variations in the rural and urban price of pineapple respectively in the study area. The F-statistics were significant at $1 \%$ probability level, indicating that, the equation has goodness of fit.

\subsection{Discussion of the Long Run and Short Run Model Results for Fresh Tomato and Pineapple}

The empirical results revealed that, the long run rural price cointegration coefficient for the fresh tomato converges to the postulate of the law of one price. This means that, this co-integration coefficient was approximately unity (0.989). This confirms the existence of high degree of long run market integration between the rural and urban prices of fresh tomato in the study area. This implies that, a shock on the urban price of fresh tomato is instantaneously transmitted to its corresponding rural price. This is conceivable when considering the flow of market information from urban to rural market. Also, the degree of market integration in the urban price equation of fresh tomato $(0.898)$ was far from the threshold mark of unity. Although these also confers high degree of long run market integration, but is not efficient as compared to the previous result. This result is tenable when market activities flow from rural to urban areas. It therefore implies that, when fresh tomato marketing activities is stimulated by the rural market, the degree of market price transmission is slower than the reverse case in the study area.

In addition, the long run model for the rural and urban price of pineapple showed similar degrees of divergence from unity (i.e. 0.809 for rural price and 0.825 for urban price equation). The rural and urban price equations however confirm the presence of significant long run market integration between the urban and rural price of pineapple; but it failed to uphold instantaneous response of the urban price to rural price shock or vice versa. This means that, irrespective of the direction of flow of pineapple marketing activities in the long run, the degree of price change in the rural and urban markets will not be instantaneous. This result indicates that, there might be some mounted externality costs in the marketing of pineapple in the study area. It is suggested that, there are some levels of inefficiency in pineapple market information transmission in the long run between the urban and rural markets in the state. This result could be connected to the poor or inefficient marketing and social infrastructures in the rural areas of the state where most of the pineapple consumed is produced. Based on the result obtained from the rural and urban price analysis of fresh tomato and pineapple in the study area; it is established that, in the long run, the price of fresh tomato in the rural markets will synchronize faster with that of the urban market if marketing shock emanated from the urban areas. This is however the reverse case for pineapple. On the other hand, if the marketing shock came from the rural area, the price transmission of fresh tomato will not attain high level of efficiency as compared to pineapple in the study area. Similar results on the long run relationships among agricultural commodities have been established by Okoh and Egbon [22]; Ohen et al.,[20]; Ojiako et al., [21] and Akpan et al., [4].

For the short run model; the estimates of the rural price equation of fresh tomato showed significant contribution of the urban price to the total variations in the rural price. The result was similar in the urban price equation. In the same manner, the short run urban price equations of pineapple showed significant coefficient of the rural price variables. However, the short run market cointegration coefficients in the rural price equation of pineapple showed significant deviations from unity (i.e. 0.557). This result implies that, though there is significant short run market integration between the urban and rural prices of fresh tomato and pineapple irrespective of the direction of flow of market activities; but the degrees of short run market -integration varies between the rural and urban areas. The short run market integration in fresh tomato appears to be stronger when information or price movement flows from urban to rural markets than the reverse case. The case is reverse in pineapple marketing in the study area. The short run results are consistent with the opinion of Okoh and Egbon [22]; Ohen et al., [20] and Akpan et al., [4].

\subsection{Index of Market Connection (IMC) for Fresh Tomato and Pineapple in Akwa Ibom State, Nigeria}

The IMC was estimated for fresh tomato and pineapple markets in the study area. The estimates of IMC regression is shown in Table 13. The IMC were 0.961 and 0.095 for fresh tomato and pineapple market respectively.

Table 13. Estimates of IMC Regression for fresh Tomato and Pineapple in Akwa Ibom State, Nigeria.

\begin{tabular}{|c|c|c|c|}
\hline \multicolumn{2}{|c|}{$\operatorname{LnFT}_{r t}=\boldsymbol{f}\left(\mathrm{LnFT}_{u t}\right)$} & \multicolumn{2}{|c|}{$\operatorname{LnP} N_{r t}=f\left(\operatorname{LnP} N_{u t}\right)$} \\
\hline Variable & $\begin{array}{l}\text { Coefficient and } \\
\text { t-test }\end{array}$ & Variable & $\begin{array}{l}\text { Coefficient and } \\
\text { t-test }\end{array}$ \\
\hline Constant & $2.870(0.33)$ & Constant & $12.498(1.43)$ \\
\hline$F T_{r t-1}$ & $0.460(4.86)^{* * *}$ & $P N_{r t-1}$ & $0.069(0.72)$ \\
\hline $\begin{array}{l}\left(F T_{u t}\right. \\
\left.-F T_{u t-1}\right)\end{array}$ & $0.782(14.40)^{* * *}$ & $\begin{array}{l}\left(P N_{u t}\right. \\
\left.-P N_{u t-1}\right)\end{array}$ & $0.559(8.08)^{* * *}$ \\
\hline$F T_{u t-1}$ & $0.501(5.15)^{* * *}$ & $P N_{u t-1}$ & $0.724(8.01)^{* * *}$ \\
\hline \multicolumn{2}{|c|}{$\begin{array}{l}\mathrm{R}^{2}=0.90 ; \text { F-cal. }=300.50 * * * ; \mathrm{DW} \\
=2.20\end{array}$} & \multicolumn{2}{|c|}{$\begin{array}{l}\mathrm{R}^{2}=0.648 ; \text { F-cal. }=61.36 * * * \\
\mathrm{DW}=2.08\end{array}$} \\
\hline
\end{tabular}

Note: Values in bracket represent t-values. The asterisks $*$ and $* * *$ represent $10 \%$ and $1 \%$ significance levels respectively. Variables are as defined in equation 3 .

The IMC for fresh tomato and pineapple are less than unity. The result implies that, there is high short run market 
integration between rural and urban markets for fresh tomato and pineapple commodities in the state. The short run market integration was stronger in pineapple market relative to the fresh tomato market. This however confirms the ECM results discussed previously and further substantiates the presence of significant short run relationship and efficient price transmission mechanism between the rural and urban price of fresh tomato and pineapple in Akwa Ibom State.

\section{Summary and Recommendations}

The study used statistical and econometric techniques to analyze the dynamic of price transmission between the rural and urban prices of fresh tomato and pineapple in Akwa Ibom State, Southern Nigeria. Results revealed that, prices of fresh tomato and pineapple in rural and urban markets have positive relationship with time and exponential growth rates that is greater than unity in fresh tomato and less than unity in pineapple. The graphical analysis showed that, there were harmonies in the rural and urban price dispersion in fresh tomato and noticeably deviations in some months in the rural and urban price of pineapple. The result of the trend analysis suggested the prevalence of good price transmission mechanism between the rural and urban market for fresh tomato and perhaps less efficient for pineapple in the study area. Also, the Pearson correlation coefficient matrix revealed that, the rural price of fresh tomato and pineapple has linear symmetric relationships with their corresponding urban prices in the study area. The relationship was stronger in fresh tomato market than in pineapple market. The result connotes the existence of the symmetric market information flow between the rural and urban markets for fresh tomato and pineapple in the state. The Granger causality test revealed bi-directional relationship between the rural and urban price of fresh tomato and pineapple in the study area. This suggested that, the price transmission mechanism between the rural and urban markets for fresh tomato and pineapple is efficient; and has high tendency for market integration as well as strong endogeneity properties.

The results of the co-integration regression revealed the presence of the long run market integration relationship between the rural and urban prices of fresh tomato and pineapple as well as upheld the hypothesis of the perfect or fast price transmission between the two markets in the study area. The results also attested to the presence of varied long run market integrations between the rural and urban market of fresh tomato and pineapple depending on the direction of flow of the market information. This means that, the rural and urban price equation of fresh tomato and pineapple exhibit varied degrees of long run market integration as well as convergence to the law of one price. The results of the short run model or error correction model (ECM), confirm the existence of the short run market integration between rural and urban prices of fresh tomato and pineapple in the study area. Similarly, the short run market integration varied in magnitude based on the direction of flow of market information or price movement between the two markets. Based on the magnitude of the coefficient of error correction term, it was discovered that, the urban price of fresh tomato adjusted faster to the stable state in the long run than the rural price once there is exogenous shock in the marketing system in Akwa Ibom State. It was also discovered that, the rural price of pineapple adjusted faster than its corresponding urban price once there is exogenous shock in the system. The estimated index of market connection (IMC) supported the high short run market integration of fresh tomato and pineapple prices in the rural and urban markets of Akwa Ibom State.

Based on the discoveries of this study, it is recommended that, the Akwa Ibom State government should continue to make available marketing infrastructures especially in the rural areas to improve the symmetric nature of information among fresh tomato and pineapple markets in the state. Effort should also be channeled by all stake holders such as governments, trade unions, market unions and other organizations to reduce excessive externality costs (i.e. storage cost, transportation cost, toll gate, law enforcement charges) associated with the marketing of fresh tomato and pineapple in the state. This attempt will help to reduce the total variable cost and bring about insignificant price differential between the rural and urban markets in the state The government of Akwa Ibom State should established market information centers and awareness programmes on mass media (such as radio, television and newspaper), to facilitate efficient communication and flow of information among fresh tomato and pineapple producers and consumers in the state.

\section{References}

[1] Adebusuyi, B. S. (2004). Stabilization of commodity market of interest to Africa: Paper presented at the workshop on constraints to growth in sub-Saharan Africa, held in Pretoria South Africa.

[2] Adenegan, K. O. and I. B. (2011). Adeoye. Price Analysis of Tomato in Rural and Urban Retail Markets of Oyo State. International Journal of Agricultural Economics \& Rural Development. Volume 4 (2): Pp 90 - 96.

[3] Adeoye, I. B, Dontsop Nguezet P. M, Badmus M. A and Amao I. O. (2011). Price Transmission and Market Integration of Banana and Plantain in Oyo state, Nigeria. ARPN Journal of Agricultural and Biological Science; Vol. 6, No. $5, \mathrm{Pp}$ 18-24.

[4] Akpan, S. B, Inimfon V. P, Samuel J. U. (2014). Analysis of Monthly Price Transmission of Local and Foreign Rice in Rural and Urban Markets in Akwa Ibom State, Nigeria (2005 to 2013). International Journal of Agriculture and Forestry; 4(1): 6-18.

[5] Akpan, S. B. (2007). Relative Price Variability and Inflation: A case study of Grain subsector in Nigeria. Unpublished Master Degree Thesis; University of Uyo. 
[6] Akwa Ibom State Agricultural Development Programme (AKADEP), quarterly physical progress reports of various issues (from January 2005 to June 2013).

[7] Amusa, A. M. (1997).Trend Analysis of Agricultural Food Prices in Nigeria (1985-1995) (A Case Study of Ibadan). Unpublished M. Sc Project, Department of Agricultural Economics, University of Ibadan, Ibadan, Nigeria.

[8] Baumöhl, E., and Tomáš Výrost (2010). Stock Market Integration: Granger Causality Testing with Respect to Non-synchronous Trading Effects. Finance aúvěr Czech Journal of Economics and Finance, 60, no. 5, Pp 414-425.

[9] Chirwa, E. W. (199). "Food Marketing Reforms and Integration of Maize and Rice Markets in Malawi. University of Malawi”. Working Paper, No. WC/05/99, 1999.

[10] Crawford, P. B, Obarzanek E., Morrison J \& Sabry Z. I. (1994). Comparative advantage of 3-day food records over 24 recall and 5-day food frequency validated by observation of 9-and 10-year girls. J Am Diet Assoc 94 (6): 626-630.

[11] Famine Early Warning Systems Network (FEWSNET) (2008). Nigeria Food Security Outlook March to September 2008 .

[12] Gilbert, C. (1999). Commodity risk management for developing countries: paper prepared for the third meeting of the international task force (ITF) held in Geneva 23-24 June 1999.

[13] Gonzalez-Rivera, G. \& S. M. (2001). The Extent, Pattern and Degree of Market Integration: A Multivariate Approach for the Brazilian Rice Market. American Journal of Agriculture Economics, 2001; 83(3), 576-92.

[14] Goodwin, B. K. \& T. C. Schroeder. (1991). "Cointegration tests and spatial price linkages in regional cattle markets." American Journal of Agricultur al Economics, 1991; 73(2): 452-464.

[15] Goodwin, B. K. (2005). Spatial and Vertical Price Transmission in Meat Markets. A Paper prepared for workshop on Market Integration and Vertical and Spatial Price Transmission in Agricultural Markets, University of Kentucky, April 21, 2005.

[16] Granger, C. W. J. (1969). Investigating causal relations by econometric models and Cross-spectral methods. Econometrica 37, 424-438.

[17] Hendry, D. F. (1986). 'The Role of Prediction in Eval uating Econometric Models', Proceedings of the Royal Society of London, 1986; 407, 25-34.

[18] Mushtaq K, Abbas F, \& Ghafoor A. (2006). Testing the Law of One Price Rice Market Integration in Punjab, Pakistan. Pakistan Journal of Agricultural Science; 43(3): 213 - 216.

[19] National Population Council (NPC) of Nigeria, 2006 Population Census Data.

[20] Ohen, S. B., S.O. Abang \& I. C. Idiong. (2007). Price Transmission and Market Integration: Vertical and Horizontal Price Linkages for Live Catfish in Nigeria. Journal of Agriculture \& Social Sciences; Vol. 3, No. 1, $17-20$.

[21] Ojiako, I. A., I. A., Chuma E, Godwin N. A \& N. M. Nkang. (2012). Spatial Integration and Price Transmission in Selected Cassava Products' Markets in Nigeria: A Case of Lafun. World Applied Sciences Journal; 18 (9): 1209-1219.

[22] Okoh, R. N \& Egbon P. C. (2005). The Integration of Nigeria's Rural and Urban Foodstuffs Markets. AERC Research Paper 151, Africa Economic Research Consortium, Nairobi, 2005.

[23] Oladapo, M. O., Momoh S, Yusuf S, \& Awoyinka Y. (2007). Marketing Margin and Spatial Pricing Efficiency of Pineapple in Nigeria. Asian Journal of Marketing; 1(1), $14-22$

[24] Odozi, J. C., and Bolarin T. O., (2012). Governance options for price instability: A review of the food grain commodity in Nigeria. Journal of Development and Agricultural Economics; Vol. 4(4), pp. 93-100.

[25] Polaski, S. (2008). Rising Food Prices, Poverty and Doha Round. Carnegie Endowment for International Peace, 2008.

[26] Quebedeaux, B. and Bliss, F. A. (1988). Horticulture and human health. Contributions of fruits and vegetables. Proc. 1st Intl. Symp. Hort. and Human Health. Prentice Hall, Englewood, NJ.

[27] Quebedeaux, B. and Eisa, H. M. (1990). Horticulture and human health. Contributions of fruits and vegetables. Proc. 2nd Intl. symp. Hort. and Human Health. HortScience 25:1473-1532.

[28] Sexton, R. J., C. L. Kling, H. F. Carman. (1991)."Market integration, efficiency of arbitrage, and imperfect competition: methodology and application to U.S. celery." American Journal of Agricultural Economics; 73(3):568-580.

[29] Van Duyn, M. A \& Pivonka E. (2000). Overview of the health benefits of fruit and vegetable consumption for the dietetics professional. J Am Diet Assoc 99 (10): 1241.

[30] Wargovich, M. J., (2000). Anticancer properties of fruits and vegetables. HortScience 35:573-575. 